\title{
Hedgerow Orientation Affects Canopy Exposure, Flowering, and Fruiting of 'Anjou' Pear Trees
}

\author{
Habib Khemira ${ }^{1}$, P.B. Lombard ${ }^{2}$, David Sugar, and \\ Anita N. Azarenko ${ }^{4}$ \\ Department of Horticulture, Oregon State University, Corvallis, OR 97331
}

Additional index words. Pyrus communis, PPF, sunlight interception

\begin{abstract}
Mature hedgerows of 'Anjou' pear (Pyrus communis L.) trees, planted north(N)south (S) or east $(E)$-west $(W)$, were used to study the effect of hedgerow orientation on fruiting and canopy exposure. In 1990, flower bud density tended to be lower on the E-W rows, especially on their $N$ sides. Fruit set (FS) was highest on the $S$ side of $E-W$ rows and lowest on the $N$ side, while the $E$ and $W$ sides of the N-S rows were intermediate. Crop density (CD) had a similar pattern as FS, with more fruit on the $S$ than on the $N$ side of the E-W rows. CD was more evenly distributed between the sides on the N-S hedgerows. Differences in FS and CD between sides were related to different levels of sunlight interception. Light exposure was lowest on the $N$ sides of the $E-W$ rows and highest on the $S$ sides throughout the growing season and especially toward the equinoxes. Increased exposure to the sun on the $S$ and $W$ sides late in the season led to more fruit with solar injury. Fruit from E-W rows were larger and less firm. Accumulated yields over 11 years showed a $21.4 \%$ increase in the $\mathrm{N}-\mathrm{S}$ rows over those of the $\mathrm{E}-\mathrm{W}$ rows.
\end{abstract}

Dry matter production of many crops is reported to be proportional to their radiant energy interception (De Jong, 1990; Jackson, 1980). Fruit trees, especially apple (Malus domestica Borkh.), respond to sunlight not only for dry matter production (Jackson and Palmer, 1977a) but also for floral initiation and yield (Auchter et al., 1926; Heinicke, 1966; Jackson and Palmer, 1977a, 1977b;

Received for publication on 2 Mar. 1992. Accepted for publication on 24 May 1993. Oregon Agricultural Experiment Station technical paper 9838. The cost of publishing this paper was defrayed in part by the payment of page charges. Under postal regulations, this paper therefore must be hereby marked advertisement solely to indicate this fact.

'Graduate Student.

${ }^{2}$ Professor.

${ }^{3}$ Assistant Professor.

${ }^{4}$ Associate Professor
Pear trees were planted in 1969 to evaluate hedgerow orientation effects on fruiting at a lower latitude $\left(42^{\circ} \mathrm{N}\right)$. A first evaluation conducted between the fifth and seventh years favored a north $(\mathrm{N})$-south $(\mathrm{S})$ orientation (Lombard and Westwood, 1977). It seemed appropriate to reevaluate these hedgerows when the trees were mature. Light quantum (in micromoles per second per square meter) received by the trees was measured and the relation between interception patterns and variation in flowering, yield, and fruit quality between the two row orientations $(\mathrm{N}-\mathrm{S}$ and $\mathrm{E}-$ W) was investigated.

The study was conducted in 1990 and Spring 1991 at the Southern Oregon Experiment Station in Medford, near lat. $42^{\circ} \mathrm{N}$, long. $124^{\circ} \mathrm{W}$, in a hot, dry climate. The average daily solar radiation during 20 growing seasons has varied from $233 \mathrm{~J} \cdot \mathrm{s}^{-1} \cdot \mathrm{m}^{-2}$ in April to $337 \mathrm{~J} \cdot \mathrm{s}^{-1} \cdot \mathrm{m}^{-2}$ in July. The plot's soil was sandy loam.

Mature 'Anjou' pear trees on Old Home $x$ Farmingdale 69,87 , or 333 rootstock, planted in 1969 , were used to study the effect of hedgerow orientation on fruiting and canopy exposure. The trees were spaced $1.2 \times 3.7 \mathrm{~m}$, trained to a central leader, and mechanically pruned to a tree wall $3.7 \mathrm{~m}$ high and $1.8 \mathrm{~m}$ wide at the base, with a wall angle $17^{\circ}$ from the vertical. The plot was divided into six blocks; each block consisted of two orientations, $\mathrm{N}-\mathrm{S}$ and E-W, with four hedgerows of each orientation. Two of the four hedgerows were used for tree performance measurements.

Tree performance was evaluated by flower cluster and fruit counts per branch cross-sectional area (BCSA) on 25 limbs per block per side $(\mathrm{N}, \mathrm{S}, \mathrm{E}$, and $\mathrm{W})$, randomly selected at $\approx 1.5 \mathrm{~m}$ above soil level. Flower buds were counted just before bloom when they were readily distinguished from vegetative buds. Fruit were counted at the end of June on the same branches. Branch diameters were measured in December at a smooth location about $5 \mathrm{~cm}$ above the branch junction. Flower bud (FD) and crop densities (CD) (count $/ \mathrm{cm}^{2}$ BCSA) and fruit set (FS) (fruit set count/100 flower clusters) were determined.

Samples of 25 fruit per side, randomly 
selected at $\approx 1.5 \mathrm{~m}$ above soil level from each of the six replicated blocks, were harvested and average fresh weight and seed content were determined. On the same fruit, flesh firmness was measured with a UC penetrometer (Western Industrial Supply, San Francisco) equipped with a 7-mm tip. Soluble solids concentration (SSC) was determined with a hand-held refractometer (ATAGO Optical Works Co., Tokyo) using juice from the lateral side (unexposed to sun) of the fruit. The fruit also were assessed for solar injury. Fruit background color was measured by placing the 8-mm-diameter measuring port of a Minolta Chroma Meter CR-200b (Minolta, Osaka, Japan) portable tristimulus calorimeter at the midpoint between the stem and calyx end on the unexposed side of the fruit. The meter was calibrated with a white standard (Minolta calibration plate CR-A43), and the fruit chromaticity was measured in $\mathrm{L}^{*} \mathrm{a} * \mathrm{~b}^{*}$ coordinates. $\mathrm{L} *$ represents the value (lightness) of colors and is larger for lighter colors; $a^{*}$ is negative for green and positive for red; and $b^{*}$ is negative for blue and positive for yellow (Singha et al., 1991). Small variations in the $-a^{*}: b^{*}$ ratio represent discernible shifts in the fruit color as perceived by the human eye (Tustin et al., 1988).

Four times (monthly) during the growing season, light exposure was measured at the same locations, starting in mid-April, on clear, sunny days. Average photosynthetic photon flux (PPF) was measured with art LI-188B photometer equipped with a quantum sensor (LI-COR, Lincoln, Neb.). Measurements were taken on two of the six blocks. The readings were taken throughout the day on each side of the tree wall, at 1- and 2-m heights and on the top, with the sensor held horizontally at the edge of the canopy. Standard readings of the maximum available light were taken under open sky.

Data were tested using analysis of variance for a randomized block design. FD and FS data were transformed using a natural log before analysis.

Measurements of PPF showed that the tree tops received more than $65 \%$ of full sunlight at any time during the growing season for both row orientations (data not shown). Light exposure above this level is of little or no value for flower initiation (Cain, 1972; Lakso et al..
1989). Cain (1971) found only a small decrease in flowering of 'McIntosh' and 'Macoun' apple trees resulting from a reduction of sunlight interception from $100 \%$ to $70 \%$. Therefore, we restricted our investigation to the middle part of the tree walls (from 1 to $2 \mathrm{~m}$ above the ground).

At any time during the growing season, tree exposure to sunlight was low early in the morning because of mutual shading, and then increased for both row orientations (data not shown). The trees oriented $\mathrm{N}-\mathrm{S}$ received a maximum PPF late in the morning, whereas the $\mathrm{E}-\mathrm{W}$-oriented trees reached that maximum later in the afternoon (Table 1). Light exposure was highest on the $\mathrm{S}$ side and lowest on the $\mathrm{N}$ side of the $\mathrm{E}-\mathrm{W}$ rows during most of the growing season (Fig. 1). The N-S-oriented rows received a higher average percentage of full sunlight than the E-W-oriented rows. This difference was less pronounced toward the equinoxes. This seasonal variation depended on the angle of incidence of the light on the $S$ side.

In 1990 , mean FD tended $(P=0.055)$ to be lower on the E-W rows, especially on their $\mathrm{N}$ sides (Table 2). The following year FD was lower on E-W rows than on N-S rows, where the $\mathrm{S}$ and $\mathrm{W}$ sides tended to have fewer flowers than the $\mathrm{N}$ and $\mathrm{E}$ sides, respectively. This result agreed with those of Lombard and Westwood (1977). The counts were <6 to 10 flower buds $/ \mathrm{cm}^{2}$, given as typical for pears (Lombard et al., 1988).

The FS differed significantly among sides of $\mathrm{E}-\mathrm{W}$ hedgerows, but not for $\mathrm{N}-\mathrm{S}$ hedgerows or between orientations (Table 2). The S side set more fruit than the $\mathrm{N}$ side. $\mathrm{CD}$ was lowest on the $\mathrm{N}$ side and highest on the $\mathrm{S}$ side of the $\mathrm{E}-\mathrm{W}$ rows (Table 2). Sides of $\mathrm{N}-\mathrm{S}$ rows were similar. Row orientations did not influence the mean CD of trees. However, the accumulated yield from 1973-80 and from 1989-91 of N$\mathrm{S}$ rows was $21.4 \%$ higher than for E-W rows (Fig. 2). The accumulated yield of $\mathrm{N}-\mathrm{S}$ rows in an adjacent block of 'Bartlett' pear with the same design was $25 \%$ higher than that of the E-W rows (unpublished data). In general, NS-oriented trees have a higher yield than those with an E-W orientation. Christensen (1979) in Denmark (lat. $55.3^{\circ} \mathrm{N}$ ) found an average yield increase of $17 \%$ with $\mathrm{N}-\mathrm{S}$ rows of apple.

Table 1. Average photosynthetic photon flux (PPF) available under open sky and at the edge of the canopy at $2 \mathrm{~m}$ height on each side of pear tree hedgerows in Medford, Ore., as measured in 1990. ${ }^{\mathrm{z}}$

\begin{tabular}{|c|c|c|c|c|c|c|c|}
\hline \multirow[b]{4}{*}{ Time (HR) } & \multicolumn{7}{|c|}{$\mathrm{PPF}\left(\mu \mathrm{mol} \cdot \mathrm{s}^{-1} \cdot \mathrm{m}^{-2}\right)$} \\
\hline & \multirow[b]{3}{*}{ Open sky } & \multicolumn{3}{|c|}{$\mathrm{E}-\mathrm{W}$ orientation ${ }^{\mathrm{y}}$} & \multicolumn{3}{|c|}{$\mathrm{N}-\mathrm{S}$ orientation ${ }^{y}$} \\
\hline & & \multicolumn{2}{|c|}{ Side } & \multirow[b]{2}{*}{ Significance } & \multicolumn{2}{|c|}{$\overline{\text { Side }}$} & \multirow[b]{2}{*}{ Significance } \\
\hline & & $\mathrm{N}$ & $\mathrm{S}$ & & $\mathrm{E}$ & $\mathrm{W}$ & \\
\hline \multicolumn{8}{|c|}{14 Apr. } \\
\hline $1000-1100$ & 1495 & 250 & 799 & $* * *$ & 1018 & 520 & $*$ \\
\hline $1300-1400$ & 1808 & 310 & 1626 & $* * *$ & 665 & 622 & NS \\
\hline $1500-1600$ & 1597 & 146 & 1407 & $* * *$ & 218 & 976 & $* * *$ \\
\hline \multicolumn{8}{|c|}{8 Sept. } \\
\hline $1000-1100$ & 1490 & 165 & 1116 & $* * *$ & 1290 & 215 & $* * *$ \\
\hline $1300-1400$ & 1747 & 96 & 1472 & $* * *$ & 580 & 773 & NS \\
\hline $1500-1600$ & 1376 & 135 & 910 & $* * * *$ & 175 & 933 & $* * *$ \\
\hline
\end{tabular}

${ }^{\mathrm{z}}$ Every value is a mean of 20 readings.

'E, east; W, west; N, north; and S, south.

${ }_{\text {ss, }, * * *}$ Nonsignificant or significant at $P \leq 0.05$ or 0.001 , respectively.

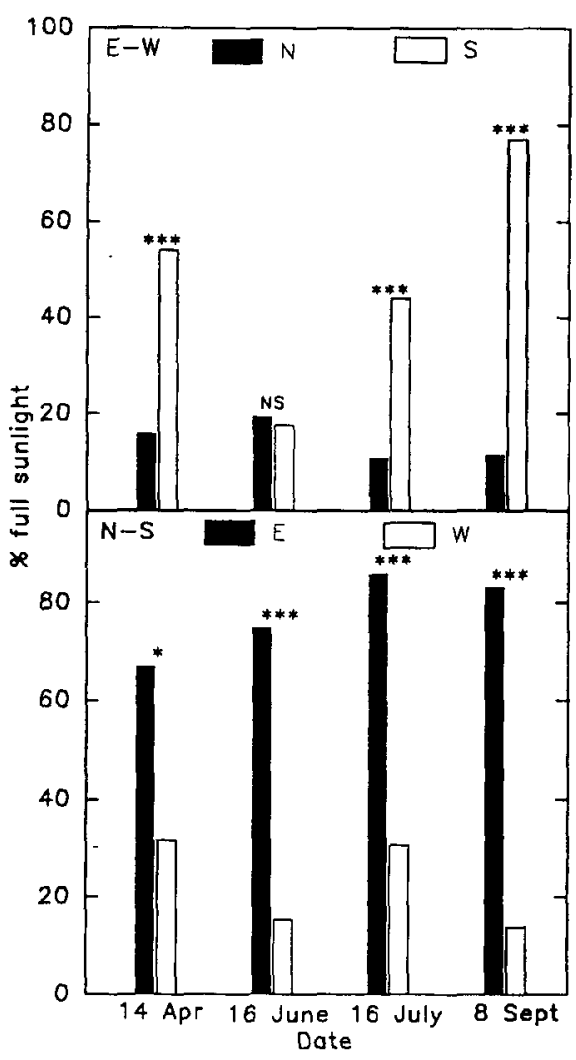

Fig. 1. Percent full sunlight received between 1000 and $1100 \mathrm{HR}$ by different sides of 'Anjou' pear hedgerows at 2-m height. The hedgerows were oriented either east (E)-west (W), with two sides facing north $(\mathrm{N})$ and south $(\mathrm{S})$, or $\mathrm{N}-\mathrm{S}$, with two sides facing $\mathrm{E}$ and W. Each bar is an average of 20 readings. NS, *, and *** denote nonsignificant or significant differences between sides within each orientation at $P \leq 0.05$ or 0.001 , respectively, on the designated measurement date.

Lombard and Westwood (1977) found yield increases of $34 \%$ and $48 \%$ for 'Williams' and 'Anjou' pear, respectively, in N-S rows compared to E-W rows in Medford, Ore. (lat. $\left.42^{\circ} \mathrm{N}\right)$. They attributed this difference to a higher bloom density on the N-S rows, because it was the only factor influenced by row orientation in their trial. They also found that trees that received more light during flower bud formation and the rest of the growing season had more flowers per unit BCSA the following year.

Many horticulturists consider $\geq 30 \%$ full sunlight as necessary for a satisfactory cropping level (Cain, 1971; De Jong, 1990; Jackson, 1980; Rom and Barritt, 1989). Palmer (1989) has shown that shading depresses flower bud initiation and development and FS, both of which are necessary to have a crop the following year. Auchter et al. (1926) found that artificial shading of 'Grimes Golden' and 'Stayman Winesap' apple trees for the whole season almost eliminated blossom bud formation. They also showed that this shading effect on flowering was limited to the shaded parts.

In our study, we observed no difference in $\mathrm{CD}$ between $\mathrm{N}-\mathrm{S}$ and E-W rows. Nevertheless, the CD of the N' side was lowest, while it was highest on the $\mathrm{S}$ side (Table 2). These 
Table 2. Influence of row orientation on flower density (FD), fruit set(FS), and crop density (CD) of 'Anjou' pear trees, Medford, Ore. ${ }^{z}$

\begin{tabular}{|c|c|c|c|c|}
\hline \multirow{2}{*}{$\begin{array}{l}\text { Orientation } \\
\text { and sidesw }\end{array}$} & \multicolumn{2}{|c|}{ FD $^{\mathrm{y}}$} & \multirow{2}{*}{$\begin{array}{c}\text { FS }^{\mathbf{y}} \\
\text { (fruit count/flower bud) }\end{array}$} & \multirow{2}{*}{$\begin{array}{c}\mathrm{CD} \\
\text { (fruit count } / \mathrm{cm}^{2} \mathrm{BCSA} \text { ) }\end{array}$} \\
\hline & 1990 & 1991 & & \\
\hline \multicolumn{5}{|l|}{$\mathrm{E}-\mathrm{W}$ rows } \\
\hline $\mathbf{N}$ & 2.7 & 5.0 & 0.40 & 1.0 \\
\hline S & 3.0 & 4.4 & 0.74 & 1.7 \\
\hline Significance & NS & $*$ & $* *$ & $* *$ \\
\hline \multicolumn{5}{|l|}{$\mathrm{N}-\mathrm{S}$ rows } \\
\hline $\mathrm{E}$ & 3.1 & 5.1 & 0.51 & 1.4 \\
\hline $\mathbf{W}$ & 2.8 & 4.7 & 0.52 & 1.3 \\
\hline Significance & NS & $*$ & NS & NS \\
\hline \multicolumn{5}{|l|}{ Orientations } \\
\hline E-W & 2.9 & 4.7 & 0.56 & 1.3 \\
\hline $\mathrm{N}-\mathrm{S}$ & 3.0 & 4.9 & 0.52 & 1.3 \\
\hline Significance & NS & * & NS & NS \\
\hline
\end{tabular}

${ }^{\mathrm{z}}$ All data are from 1990 season unless otherwise indicated. Values for each side represent the mean of at least 150 limbs (300 limbs per orientation).

${ }^{y} \mathrm{FD}$ and FS data were transformed using natural log for mean separation analysis. Actual values are presented in the table.

${ }^{x}$ BCSA, branch cross-sectional area, measured $5 \mathrm{~cm}$ above the branch junction.

${ }^{\text {wE}} \mathrm{E}$, east; W, west; $\mathrm{N}$, north; and $\mathrm{S}$, south.

Ns, ${ }^{*}, * *$ Nonsignificant or significant at $P \leq 0.05$ or 0.01 , respectively.

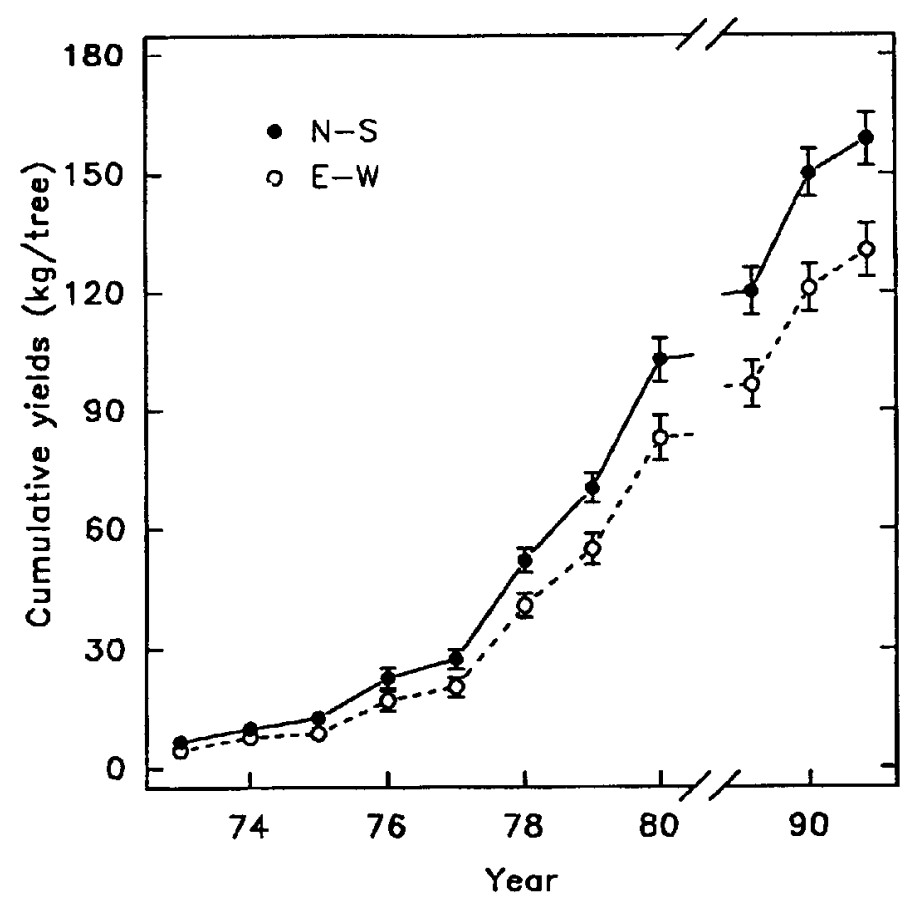

Fig. 2. Average cumulative yield per tree of 'Anjou' pear hedgerows oriented either N-S or E-W. From 1973 to 1980 , every point is an average yield of 240 trees, and from 1989 to 1991 , every point is an average yield of 36 trees. Vertical bars represent SE of the mean. $\mathrm{N}$ is north, $\mathrm{S}$ is south, $\mathrm{E}$ is east, and W is west.

differences appeared to be related more to FS $(r=0.76, P<0.03)$ than to FD. In fact, in 1990, FD was low on all sides, but FS followed a pattern similar to CD levels, highest on the $\mathrm{S}$ side and lowest on the $\mathrm{N}$ side. This pattern may have been due to better conditions for pollination and fertilization during bloom of the $S$ side of E-W rows. Bee activity is lower on the shaded sides of trees and on cold and windy days (Westwood, 1978). However, pollination was apparently not responsible for the differences in FS, because seed content was high in fruit from all sides (5.9 to 6.2). Environmental conditions during bloom were favorable for pollination and FS. The mean temperature was $4.5 \mathrm{C}$ higher than the long-

with high $\mathrm{N}$ content have a longer effective pollination period and ovule longevity and set more fruit (Khemira, 1991; Williams, 1965). Sanchez et al. (1990) showed that leaves translocate their $\mathrm{N}$ preferentially to storage structures and flower buds before senescing in fall. Furthermore, leaf photosynthetic capacity and leaf $\mathrm{N}$ content are apparently partitioned among leaves within a plant canopy with respect to natural field light exposure (De Jong and Doyle, 1985; De Jong et al., 1989; Hirose and Werger, 1987). Therefore, the improved set (Table 2) observed on the more exposed canopy areas (Table 1) maybe related to higher availability of reserves for the flowers early in the season.

Fruit from the E-W rows were heavier $(164 \mathrm{~g})$ than fruit from N-S rows $(150 \mathrm{~g})$ (Table 3). Fruit weight was best correlated with $\mathrm{CD}(r=-0.76, P<0.03)$. Fruit from the $\mathrm{E}-\mathrm{W}$ rows also were softer than fruit from $\mathrm{N}-$ $S$ rows. Row orientation had little influence on skin color, but $\mathrm{N}$ - and $\mathrm{W}$-facing fruit were greener than those facing $\mathrm{S}$ or $\mathrm{E}$, respectively. There were no differences among either sides or row orientations for SSC (14.1\% to $14.3 \%$ ). Lombard and Westwood (1977) found that full bloom was advanced 2 days on the $S$ side and delayed 2 days on the $\mathrm{N}$ side compared to the $\mathrm{E}$ and $\mathrm{W}$ sides. However, they found no differences in maturity between either sides or orientations. In the present study, if firmness is used as a reliable maturity indicator for pears, fruit from E-W rows were more mature than those from the N-S rows on the sampling date (8 Sept. 1990).

Solar injury was most severe on the $\mathrm{S}$ and $\mathrm{W}$ sides and least on the $\mathrm{N}$ and $\mathrm{E}$ sides of the hedgerows (Table 3). However, it was not influenced by row orientation. It was correlated $(r=0.75, P=0.03)$ with sunlight exposure recorded on the afternoon of 8 Sept. 1990.

The $\mathrm{E}$ and $\mathrm{W}$ sides of the $\mathrm{N}-\mathrm{S}$ rows received equal sun exposure throughout the growing season. The E side had more flower buds and fruit per unit BCSA than the W side, and fruit were darker yellow but had less solar injury. This difference may be related to the exposure of the E sides to sunlight early in the day, which might result in an early daily saturation of photosynthesis. The $\mathrm{W}$ sides had higher PPF in the afternoons (Table 1) when air temperature was generally high and the relative humidity was low. These conditions are less favorable for photosynthesis and could predispose fruits to solar injury (Table 3 ).

Differences between the three rootstock were very small; therefore, they were ignored (data not shown).

Consideration of hedgerow orientation should be based on several factors presented in this study and others. Generally, in areas with conditions similar to those in Oregon, N-S hedgerow orientation should be preferred in orchards similar to the one used in this study. These also were the conclusions of Cain (1972), Jackson and Palmer (1972), and Lombard and Westwood (1977). However, other orientations maybe more favorable if the topography, air movement, and irrigation dictate orchard management.

\section{Literature Cited}

Auchter, E.E., A.L. Schrader, F.S. Lagassee, and W.W. Aldrich. 1926. The effect of shade on the growth, fruit bud formation and chemical com- 
Table 3. Effect of hedgerow orientation on characteristics of 'Anjou' pear fruit (Medford, Ore., 1990). ${ }^{\mathrm{z}}$

\begin{tabular}{|c|c|c|c|c|}
\hline $\begin{array}{l}\text { Orientations } \\
\text { and sides }\end{array}$ & $\begin{array}{c}\text { Fruit } \\
\text { wt (g) }\end{array}$ & $\begin{array}{l}\text { Firmness } \\
(\mathrm{N})\end{array}$ & $\begin{array}{c}\text { Background } \\
\operatorname{color}^{x}\left(-a^{*}: b^{*}\right)\end{array}$ & $\begin{array}{l}\text { Fruit with } \\
\text { SI" }^{w}(\%)\end{array}$ \\
\hline \multicolumn{5}{|l|}{$\overline{E-W}$ rows } \\
\hline $\mathbf{N}$ & 167 & 48 & 0.417 & 2.7 \\
\hline $\mathbf{S}$ & 160 & 52 & 0.407 & 13.3 \\
\hline Significance & NS & $*$ & $*$ & $* * *$ \\
\hline \multicolumn{5}{|l|}{$\mathrm{N}-\mathrm{S}$ rows } \\
\hline E & 148 & 51 & 0.411 & 1.3 \\
\hline W & 151 & 56 & 0.418 & 7.3 \\
\hline Significance & NS & ** & $*$ & $*$ \\
\hline \multicolumn{5}{|l|}{ Orientations } \\
\hline E-W & 164 & 50 & 0.412 & 8.0 \\
\hline $\mathbf{N}-\mathbf{S}$ & 150 & 54 & 0.415 & 4.3 \\
\hline Significance & $* * *$ & ** & NS & NS \\
\hline
\end{tabular}

${ }^{2}$ Values for each side represent a mean of 150 fruit (300 fruit per orientation).

'E, east; W, west; N, north; and S, south.

${ }^{x}$ Background color derived from the ratio of green $\left(-a^{*}\right)$ to yellow $\left(b^{*}\right)$ color of the total chromaticity of the fruit skin, measured according to the $\mathrm{L}^{*} \mathrm{a}^{*} \mathrm{~b}^{*}$ color system.

"SI is solar injury.

ss,****** Nonsignificant or significant at $P \leq 0.05,0.01$, or 0.001 , respectively.

position of apple trees. Proc. Amer. Soc. Hort. Sci. 23;368-382.

Cain, J.C. 1971. Effect of mechanical pruning of apple hedgerows with a slotting saw on light penetration and fruiting. J. Amer. Soc. Hort. Sci. 96:664-667.

Cain, J.C. 1972. Hedgerow orchard design for most efficient interception of solar radiation. Effect of tree size, shape, spacing, and row direction. New York State Agr. Expt. Sta., Res. Agr. 2(7):114.

Christensen, J.V. 1979. Effects of density, rectangularity and row orientation on apple trees, measured in a multivariated experimental design. Scientia Hort. 10:155-165.

De Jong, T.M. 1990. Canopy and light management. Proc. California Pear Course, 1990.

De Jong, T.M., K.R. Day, and R.S. Johnson. 1989. Partitioning of leaf nitrogen with respect to within canopy exposure and nitrogen availability in peach (Prunus persica). Trees 3:89-95.

De Jong, T.M. and J.F. Doyle. 1985. Seasonal relationships between leaf nitrogen content (photosynthetic capacity) and leaf canopy light exposure in peach (Prunus persica). Plant Cell Environ. 8:701-706.
Devyatov, A.S. and A.V. Gorny. 1978. Effect of espalier orientation on light status and cropping of apple trees. Fruit Sci. Rpt. 5(4):1-8.

Ferguson, J.H.A. 1960. A comparison of two planting systems in orchards as regards the amount of radiation intercepted by the trees. Neth. J. Agr. Sci. 8:271-280.

Heinicke, D.R. 1966. The effect of natural shade on photosynthesis and light intensity in 'Red Delicious' apple trees. Proc. Amer. Soc. Hort. Sci. 88:1-8.

Hirose, T. and M.J.A. Werger. 1987. Nitrogen use efficiency in instantaneous and daily photosynthesis of leaves in the canopy of a Solidago altissima stand. Physiol. Plant. 70:215-222.

Jackson, J.E. 1980. Theory of light interception by orchards and a modelling approach to optimizing orchard design. Acta Hort. 114:69-79.

Jackson, J.E. and J.W. Palmer. 1971. Light distribution within hedgerow orchards. Rpt. East Mailing Res. Sta. for 1970.

Jackson, J.E. and J.W. Palmer. 1972. Interception of light by model hedgerow orchards in relation to latitude, time of year and hedgerow configuration and orientation. J. Applied Ecol. 9:341357.
Jackson, J.E. and J.W. Palmer. 1977a. Effect of shade on the growth and cropping of apple trees. I. Experimental details and effects on vegetative growth. J. Hort. Sci. 52:245-252.

Jackson, J.E. and J.W. Palmer. 1977b. Effects of shade on the growth and cropping of apple trees. II. Effects on components of yield. J. Hort. Sci. 52:253-266.

Khemira, H. 1991. Influence of canopy orientation on fruiting of 'Anjou' pears and postharvest urea spray on ovule longevity and fruit set of 'Comice' pears. MS Thesis, Oregon State Univ., Corvallis.

Lakso, A.N., T.L. Robinson, and S.G. Carpenter. 1989. The palmette leader A tree design for improved light distribution. HortScience 24:271275

Lombard, P.B., N.W. Callan, F.G. Dennis, Jr., N.E Looney, G.C. Martin, A.R. Renquist, and E.A. Mielke. 1988. Towards a standardized nomenclature, procedures, values, and units in determining fruit and nut tree yield performance. HortScience 23:813-817.

Lombard, P.B. and M.N. Westwood. 1977. Effect of hedgerow orientation on pear fruiting. Acta Hort. 69:175-182.

Palmer, J.W. 1989. Canopy manipulation for optimum utilization of light, p. 245-252. In: C.J. Wright (ed.). Manipulation of fruiting. Butterworth, London.

Rom, C.R. and B.H. Barritt. 1989. Light interception and utilization in orchards, p. 41-58. In: A.B. Peterson (ed.). Intensive orcharding. Good Fruit Grower, Yakima, Wash.

Sanchez, E.E., T.L. Righetti, D. Sugar, and P.B. Lombard. 1990. Response of 'Comice' pear trees to a postharvest urea spray. J. Hort. Sci. 65:541-546.

Singha, S., E.C. Townsend, and T.A. Baugher. 1991. Relationship between visual rating and chromaticity values in 'Delicious' apple strains. Fruit Var. J. 45:33-36

Tustin, S., P.M. Hirst, and J. Warrington. 1988. Influence of orientation and position of fruiting laterals on canopy light penetration, yield, and fruit quality of 'Granny Smith' apple. J. Amer. Soc. Hort. Sci. 113:693-699.

Westwood, M.N. 1978. Temperate zone pomology. Freeman, San Francisco.

Williams, R.R. 1965. The effect of summer nitrogen applications on the quality of apple blossom. J. Hort. Sci. 40:31-41. 